\title{
UNDERSTANDING NREGA: A SIMPLE THEORY AND SOME FACTS
}

\author{
Diganta Mukherjee \\ Email: digantam@hotmail.com \\ Unitedworld School of Business \\ Kolkata

\begin{abstract}
Uday Bhanu Sinha
Email: uday@econdse.org

University of Delhi
\end{abstract} \\ Delhi School of Economics
}

Working Paper No. 196

Centre for Development Economics

Department of Economics, Delhi School of Economics 


\title{
Understanding NREGA: A Simple Theory and Some Facts*
}

\author{
Diganta Mukherjee" ${ }^{\#}$ and Uday Bhanu Sinha
}

\begin{abstract}
A developing economy like India is often characterised by a labour market with demand and supply of labour and a wage that even if competitively determined may not be adequate for the poor household to reach their target income; what they consider as means of a decent living. Envisaging situations like these, the Indian government has implemented the National Rural Employment Guarantee Act (NREGA) in recent past, to complement the income of the poor by providing them employment for certain number of labour days in a year. In this paper, using a simple theoretical model, we have analysed the impact of NREGA scheme on (i) rural labour market, (ii) income of the poor households and (iii) overall agricultural production. It is seen that the income from NREGA alone can be a substantial part of the target income of the poor. We show that in such a situation, the poor may exhibit a backward bending supply curve of labour which may lead to an aggregate reduction in agricultural output. This adverse production effect can happen even when the NREGA activities lead to a moderate improvement in agricultural productivity. Data on food prices tend to support our finding to some extent.
\end{abstract}

Keywords: NREGA, target income, labour supply, agricultural productivity, India, Asia

JEL Classification: I38, J22, J43

Corresponding Author: Uday Bhanu Sinha, Department of Economics, Delhi School of Economics, University of Delhi, Delhi 110007, India. Fax: +91-11-2766 7159

Email: uday@econdse.org

\footnotetext{
* Acknowledgement: We are grateful to Nancy Chau, Deepti Goel and Bishwantath Goldar for helpful comments on an earlier version of this paper.

\# Diganta Mukherjee, Unitedworld School of Business, Kolkata, India, digantam@hotmail.com
} 


\section{Introduction}

The policy of employment guarantee scheme (EGS) is well known since the 1817 Poor Employment Act and the 1834 Poor Law Amendment Act in Great Britain (Blaug, 1963, 1964), and the New Deal programs of the 1930s in the United States (Kesselman, 1978; Bernstein, 1970), and it was considered an important element of relief policies during natural disasters and economic downturns. In recent past, this kind of schemes were followed both in developed and developing countries with multiple objectives such as poverty reduction, building and maintaining public infrastructure, improving bargaining power of the workers etc. Among others, some notable examples of such schemes mainly for poverty alleviation are as followed by Chile (1987), India (1978), Pakistan (1992), Bangladesh (1983), Philippines (1990), Botswana (1960, Kenya (1992).

The EGS is a policy of direct transfer to the poor through the provision of public works (Drèze and Sen, 1991; Lipton 1996; von Braun, 1995) satisfying the property of self selection (Besley and Coate, 1992; Besley and Kanbur, 1993) and the magnitude of such direct transfer benefits was empirically studied (Ravallion,1991; Ravallion et al.,1993). The earlier studies on rural public works programs emphasized its role as income insurance in the presence of seasonality in agrarian labour market (Basu, 2007), for building longer term capital assets (Basu, 1981), preventing dislocation of families in search of jobs and food (Drèze and Sen, 1991), affecting rural-urban migration (Ravallion, 1990).

Though the policy of employment guarantee schemes are commonly followed by governments in both developing and developed countries alike as a relief policy, there is very little by way of formal theoretical modelling to understand the issue. Recently Basu et al (2010) provides a theoretical framework to analyse both the positive and normative implications of such a policy in a spectrum of labour market structures. While the introduction of such a scheme introduces a contestability in the labour market where government is another employer, however the outcome with respect to wages and overall level of employment in the labour market would depend on the "degree of distributional and/or efficiency concerns of the planner". In this paper, we analyse the impact of NREGA scheme on (i) rural labour market, (ii) income of the poor households and (iii) overall agricultural production. When the income from NREGA alone can be a substantial part of the target income of the poor, the poor may exhibit a backward bending supply curve of labour which may lead to an aggregate reduction in agricultural output. This adverse production effect can happen even when the NREGA activities lead to a moderate improvement in agricultural productivity.

Consider the scenario where there exists a labour market with demand and supply of labour and a wage rate. Even if the wage is competitively determined, it may not be adequate for the poor household to reach their target income; what they consider as means of a decent living for their 
households. Envisaging situations like these, the Indian government from time to time has implemented different policies to complement the income of the poor. The National Rural Employment Guarantee Act (NREGA) is one such policy of EGS which is introduced in recent past. Passed by the Lok Sabha on August 23, 2004 and signed by the President of India on September 5, 2005, NREGA has been hailed as a major initiative in the Government of India's commitment to providing an economic safety net to India's rural poor. The NREGA extends to all rural areas of India, including Fifth and Sixth Schedule areas, except the State of Jammu and Kashmir. In this paper we would provide a conceptual framework and also some empirical facts for understanding the different plausible impacts of NREGA. Some of the impacts have already been documented by different studies (see Mathur, 2007; Mehrotra, 2008). In the following subsections we first outline the scope of the scheme and the debate that surrounds it.

\subsection{The Scheme: National Rural Employment Guarantee Act of India, $2005^{1}$}

Data show that $71.9 \%$ of India's population still resides in rural areas (2002), and given that the majority of India's poor also resides in rural areas, the NREGA can be thought of as a policy to boost rural income, stabilize agricultural production and reduce the population pressure in urban areas through migration.

Some of the original provisions of the NREGA were as outlined below.

(i) Every household in the rural areas of India shall have a right to at least 100 days of guaranteed employment every year for at least one adult member, for doing casual manual labour at the rate of Rupees 60 per day;

(ii) Only productive works shall be taken up under the Programme. The State Council shall prepare a list of permissible works as well as a list of "preferred works". The identification of preferred works shall be based on the economic, social and environmental benefits of different types of works, their contribution to social equity, and their ability to create permanent assets;

(iii) The Programme may also provide, as far as possible, for the training and up-gradation of the skills of unskilled labourers;

(iv) Wages may be paid in cash or in kind or both, taking into account the guidelines and recommendations of the State Council on this matter as far as possible;

(v) Employment shall be provided within a radius of 5 kilometres of the village where the applicant resides at the time of applying. In cases where employment is provided outside such radius, it must be provided within the Block, and transport allowances and daily living allowances shall be paid in accordance with Programme Rules;

\footnotetext{
${ }^{1}$ This section borrows from Basu, Chau and Kanbur (2005).
} 
(vi) In cases where at least twenty women are employed on a worksite, a provision shall be made for one of them to be deputed to look after any children under the age of six who may be brought to the worksite, if the need arises. The person deputed for child-minding shall be paid the statutory minimum wage;

(vii) A proportion of the wages, not exceeding 5\%, may be deducted as a contribution to welfare schemes organized for the benefit of labourers employed under the Programme, such as health insurance, accident insurance, survivor benefits, maternity benefits and social security schemes. ${ }^{2}$

The NREGA scheme also comes with two important riders:

(i) Public works programmes should not compete with agricultural labour hiring decisions and

(ii) Public works programmes should generate a productive asset that directly impacts agricultural productivity.

However, with most of Indian agriculture characterized by seasonality - a lean season when agricultural labour demand is low and a harvest season when labour demand is high - it was reasonably assumed that the public employment, guaranteed for at least 100 days, will be instituted during the lean season when the rural labour force is most vulnerable. Some of the performance parameters of the scheme are illustrated in Table 1, where we outline the spread of the programme in different states of the country, in terms of number of districts covered, funds and its utilisation, coverage in terms of man-days and number of households covered. The general pattern of these performance indicators remains stable even up to $2010-11$. $^{3}$

\subsection{The Debate}

NREGA is supposed to alleviate rural poverty, but the operational dimensions of the NREGA have been subject to much debate regarding the efficacy and targeting of the act. NREGA has attracted mixed reactions from economists and policy analysts. ${ }^{4}$ There has been considerable discussion on whether the employment has been successfully targeted to the poor, or there are leakages to those above the poverty line. The most detailed evaluation so far has been undertaken by Dreze and Khera

\footnotetext{
${ }^{2}$ There are eight specific types of works listed in the NREGA: (i) water conservation and water harvesting; (ii) drought proofing including afforestation; (iii) irrigation canals; (iv) provision of irrigation facility to land-owned by SC and ST, land of beneficiaries of land reforms and of Indira Awaas Yojana (IAY) (rural housing for poor); (v) renovation of traditional water bodies; (vi) land development; (vii) flood control works; (viii) rural connectivity to provide all weather access; and (ix) any other work, which may be notified by central government in consultation with state government (see Mehrotra, 2008 for more discussion on this issue) . ${ }^{3}$ All the data cited in this paper are from the relevant Government of India websites like http://www.agricoop. nic.in/ and http://nrega.nic.in/netnrega/home.aspx. Further calculations are done by authors.

${ }^{4}$ Much has been written about NREGA both in favour and against the programme. Some argued that the NREGA was unnecessary because in any case poor agricultural workers had a very low unemployment rate (Business Standard, December 25, 2004).
} 
(2009), covering six states in 2007-08. Dreze and Khera (2009) find that $98 \%$ of the sample workers stated that they were ready to work for 100 days in the year - the "upper limit" under the Act. NREGA as of now meets only a fraction of this demand: in their survey only $13 \%$ of the respondents had actually secured 100 days of NREGA work in the preceding 12 months. There are, of course, wide inter-State variations in this respect. While the proportion of sample workers who had completed 100 days of work was particularly low in Chhattisgarh (1\%), Bihar (2\%), Uttar Pradesh (3\%) and Jharkhand (7\%), it was considerably higher in Madhya Pradesh (17\%), and as high as $35 \%$ in Rajasthan. Also see Table 2, columns 7 and 8 for a state-wise breakdown of employment provided (person-days). The numbers are all well below the target. Again, checking more recent data (updated till 2010 - 11) reveals small improvement in performance.

We start with the presumption that rural labour markets in India do not conform to the classic competitive labour markets of economics textbooks. If they did, the arguments for the NREGA would be weaker. In fact, the labour market in rural India can best be characterized as imperfect with high costs on the part of workers to seek and to switch employment, and with elements of collusion and social power on the part of employer that lead to low wages, and above all to equilibrium unemployment.

Assuming the NREGA targets this group of unemployed workers, the possibility of an alternative source of income raises the reservation wage of all workers in the rural sector, and implicitly confers some bargaining power to rural workers. Thus, it is clear that the fact of a guarantee of employment at a given wage through the NREGA would introduce contestability in the rural labour market. In other words, in the presence of NREGA scheme the large land holders in rural areas may now need to raise wage of workers they hire in order to ensure the necessary supply of labour.

The key questions are whether the NREGA can have fruitful impact on poverty, raise private sector wages and overall employment for rural labour force. Will it lead to higher aggregate production? The answers essentially lie in how the labour supply schedule available to large land holders in agriculture react to the opposing effects of the NREGA. On the one hand, the NREGA scheme provides an alternative source of employment and which may lead to a reduction in the pool of workers available for private employer in a particular year and also the potential contestability effect of the NREGA in terms of higher wage reduces the demand for labour in private employment; on the other hand, there is positive effect in terms of higher productivity in agriculture. Though the eventual outcome is more 
of a matter of empirical investigation but here in this paper we would provide some theoretical predictions with the help of a baseline model. ${ }^{5}$

We outline a simple theoretical model for the above discussions in the following section looking at the (im)perfection of the labour market and the effect of NREGA in the rural labour supply decision. We go on to discuss the aggregate production consequences, considering alternative productivity implications of the scheme in section 3. Section 4 concludes with some future directions of research.

\section{A Simple Theoretical Model}

Consider a rural economy with two types of households: rich and poor. There are $m$ number of rich households and $n$ number of poor households (reasonably, we assume that $m<n$ ). Each household has $\mathrm{L}$ number of labour days available in a year. The rich household has enough land $(\mathrm{K})$ in their disposal and as a result they would like to employ more labour from outside the household at a reasonable wage. Therefore, they would be net buyer of labour service. On the other hand, the poor household has little land to work with $(\mathrm{k}<\mathrm{K})$ and as a result each poor household has excess supply of labour which they can sell in the market. The agricultural production functions for both rich and poor households are the same, $\mathrm{Q}=\mathrm{f}($.$) is a function of land and labour, and it is only the endowment of$ land that is different. Given that there is not much sales and purchase of land happening in rural India, we assume that land market does not exist and each household whether rich or poor has fixed amount of land which is part of the inherited property. ${ }^{6}$

Thus, the rich household has the production $\mathrm{f}(\mathrm{K},$.$) and the poor household has the production \mathrm{f}(\mathrm{k},$. depending on their choice of employment of labour. Given the fixed endowment of land the production function satisfies the usual properties of first and second derivatives with respect to labour. That is, the marginal productivity of labour is positive and downward sloping curve. However, keeping in view the features of agricultural production process we take the marginal productivity curve of labour to attain zero after some labour employment on any fixed plot of land. ${ }^{7}$

\footnotetext{
${ }^{5}$ The productive value of NREGA works is also something of a mystery. The general impression is that they are mostly useless. Some dismissed them as a futile attempt "to play with mud, to create a road that goes from nowhere to nowhere, to dig ditches that will be washed away in the next monsoon" (Hindustan Times, February $14,2008)$. This verdict, however, is hard to substantiate or negate and we leave this again as a subject of empirical enquiry.

${ }^{6}$ Basu et al (2010) found in their sample that $94 \%$ of land is inherited while $2 \%$ is purchased and the rest of land is obtained either as gifts, or through share cropping or through encroachment of village commons or forests.

${ }^{7}$ The standard textbook in Development Economics always work with such a scenario (for instance, see Basu, (1997) and Ray (1998)).
} 


\subsection{Perfect labour market:}

Given the production function, in perfect labour market without a friction, the equilibrium wage would be established at a wage where the total supply of labour from the poor household is equal to the total demand for labour from the rich household. Define the equilibrium wage as $\mathrm{w}^{*}$.

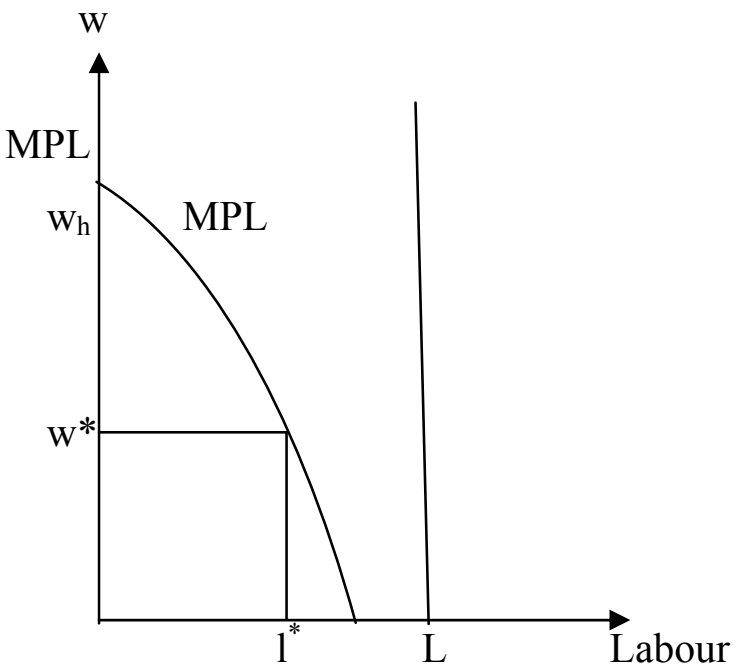

Figure 1: (a) Poor household's own employment

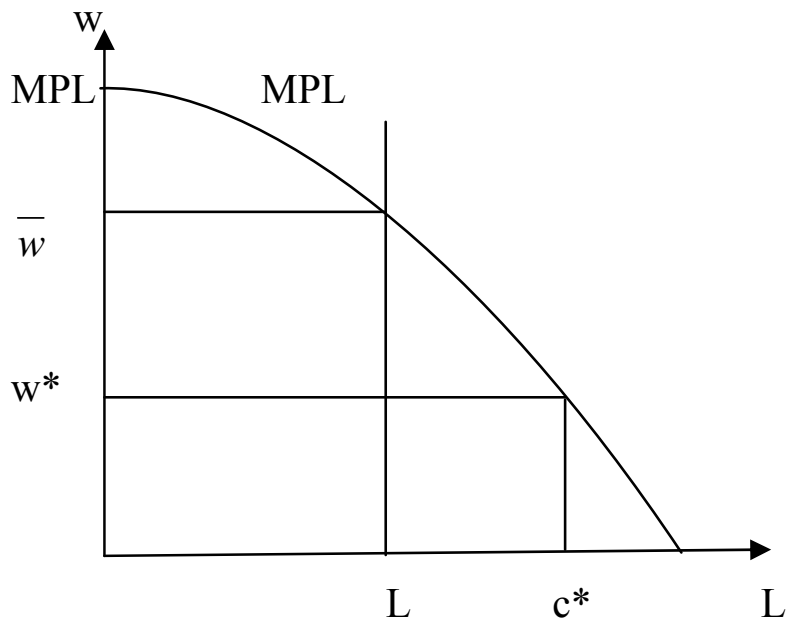

1: (b) Rich household's own employment (L) and thus, MPL to the right of $\mathrm{L}$ is the labour demand curve of the rich households.

At $\mathrm{w}^{*}$ the poor household employs an amount of labour say $1 *$ in their own land. So the excess labour supply they have is $L-1^{*}$. Thus, the total supply of labour would be $n\left(L-1^{*}\right)$. At $w^{*}$ suppose the rich wants to employ c* amount of labour (given the marginal productivity of labour on their land. Out of $\mathrm{c}^{*}$ the rich employs their own supply $\mathrm{L}$ and any additional labour they need they demand it from the market. Thus the demand for labour for the rich household at $\mathrm{w}^{*}$ is $\mathrm{c}^{*}-\mathrm{L}$ per household. Therefore, the total demand for labour for the rich households would be $\mathrm{m}\left(\mathrm{c}^{*}-\mathrm{L}\right)$. In the perfect labour market $\mathrm{w}^{*}$ would be such that

$$
\mathrm{n}\left(\mathrm{L}-1^{*}\right)=\mathrm{m}\left(\mathrm{c}^{*}-\mathrm{L}\right) .
$$

It is clear from the behaviour of the marginal productivity of labour curves that RHS is a decreasing function of $\mathrm{w}$ and the LHS is an increasing function of $\mathrm{w}$. With some additional regularity assumptions it is possible that competitive labour market equilibrium exists and it would be obtained at a unique wage level $\mathrm{w}^{*}$.

Given the labour demand of the rich household and the supply of labour of the poor household we draw in the next panel the market demand and supply of labour which is the horizontal sum of the demand for labour from all rich households and the supply of all poor households. 
If the equilibrium wage is above some $\mathrm{w}_{\mathrm{h}}$ then the poorer household would stop their own cultivation and supply the entire labour force for the cultivation of the rich households. But given the current scenario where $m<<n$, this is unlikely to happen. Also, if $m$ is so low that $\mathrm{w}^{*}$ is driven down to zero, then due to biological subsistence restrictions, the prevailing subsistence wage will be greater than the market clearing wage. There will be unemployment as the people willing to work would not receive the employment due to lack of demand from the rich households. This excess labour would naturally work on their own land and might even drive the marginal productivity of their family cultivation to zero. Thus, we will have a situation of labour surplus economy.

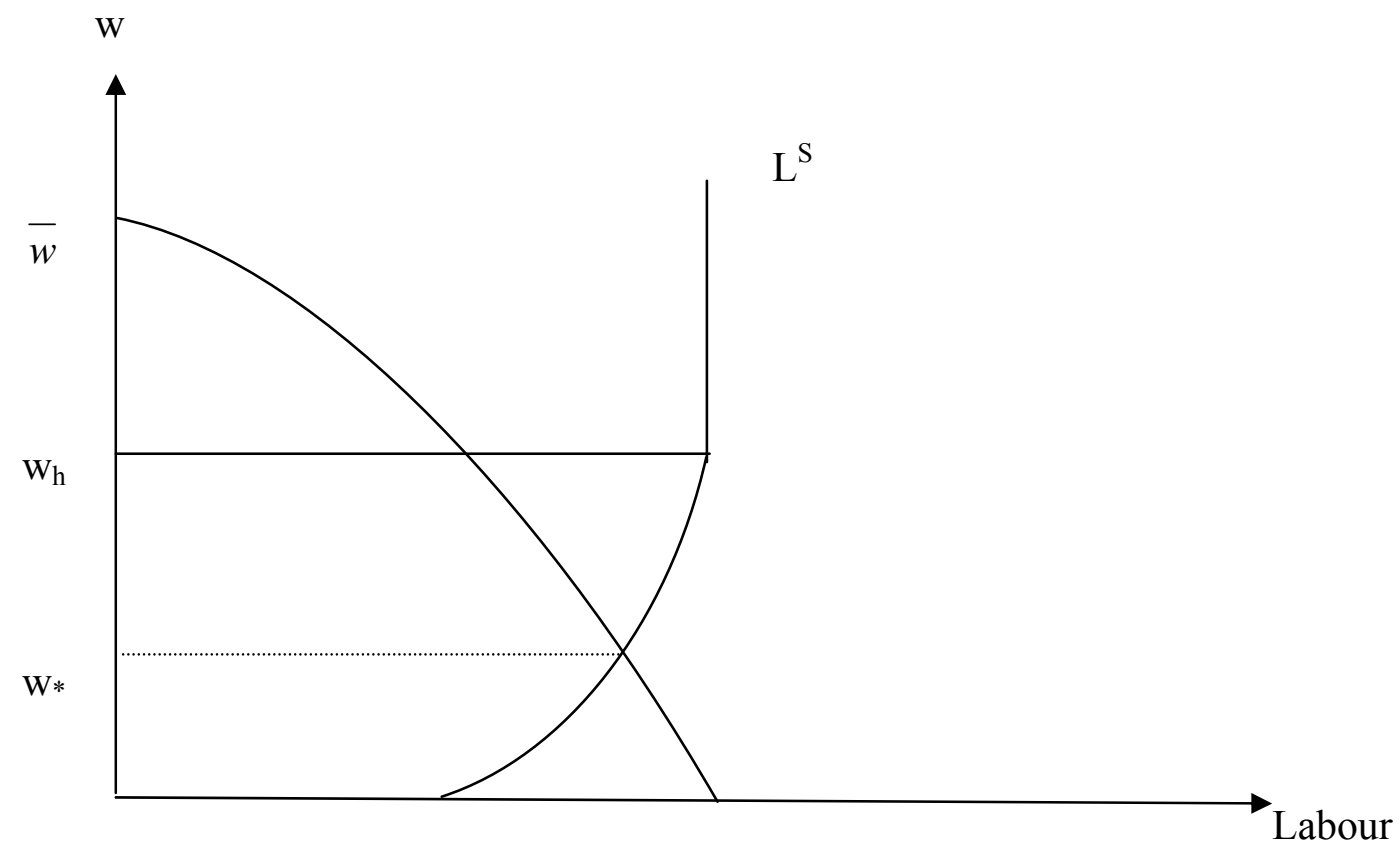

Figure 2: Equilibrium in the perfect labour market (Demand for and supply of labour)

On the other hand, we may have a well functioning perfect labour market when the demand and supply intersect at a reasonable wage above subsistence and the equilibrium is obtained at $\mathrm{w}^{*}$. For the labour market to function we need that (i) the demand and supply of labour curves are well behaved and (ii) they have an intersection at a positive wage above subsistence wage. In order to achieve such well behaved demand and supply curves it must be the case that both types of household maximises their income and also the utility is a monotonically strictly increasing function of income for both types of household. In order to ensure the intersection in the relevant economic range of wages the population of rich and poor should be in certain proportion. As mentioned above, if there are too many poor household as compared to rich we will have labour surplus economy. 
It is possible to have a situation where even though the labour market is perfect and we have an equilibrium wage determined by the market forces of demand and supply; the poor households may not receive adequate income in order to maintain a decent living or else at least maintain a living above the relevant poverty line of income.

It is obvious that when a programme like NREGA is introduced in a perfectly functioning labour market and assuming that NREGA work is preferred over working for the rich households at all wages then the supply curve of the labour would shift leftward, leading to a higher market clearing wage. In such a situation the poor and rich household would employ less labour for agricultural cultivation. As a result, the total agricultural production will fall. On the other hand, if there is surplus labour in the economy and in case the NREGA works are provided just to absorb that surplus labour then there may not be any adverse effect on agricultural production. Of course, this prediction is based on the assumption that NREGA works are not creating any permanent asset which can impinge on the productivity of land.

\subsection{Imperfect labour market:}

It has been revealed by various studies undertaken in rural India that the labour market is not perfect and the wages are typically suppressed far below the competitive wage due to the presence of extraeconomic coercion and other factors such as feudal forces exerted by the rich households or caste. Also in some regions due to population pressure the prevailing wages as well as the works available are not adequate for the poor households for a sustainable living which often leads to large scale migration. Thus the existence of surplus labour in agriculture at the prevailing wage is a feature of labour market which does not go well with the assumption of perfect labour market. ${ }^{8}$

Consider that all poor households have a target level of income, say $T$. $T$ can well be interpreted as the poverty line or a level of income which the poor household aspires to achieve for their decent living. In other words this can be interpreted as an aspiration income level of the poor household. Another way of stating this is that the utility function from income for the poor is concave up to the income level $T$ and then flattens out such that there is no extra utility from any addition to income beyond $T .^{9}$ Let $y$ represent income.

Formally, $\mathrm{U}_{\mathrm{p}}=\mathrm{u}(\mathrm{y})$ where $\mathrm{u}^{\prime}(\mathrm{y})>0$ and $\mathrm{u}^{\prime \prime}(\mathrm{y})<0$ for $\mathrm{y}<T$ and

\footnotetext{
8 There is evidence that the labour market is imperfect and characterized by market power in both rural and urban areas (Bardhan and Rudra,1981; Bardhan, 1979, 1984; Binswanger et al., 1984; Card and Krueger, 1995; Datt, 1997; Manning, 2005).

${ }^{9}$ Basu et al (2010) used a similar utility function for the household in the context of child labour supply. They found that given the fixed target income of the household, the child labour supply behaves as inverted U shaped with respect to the landholding of the household.
} 


$$
\text { and } \mathrm{u}^{\prime}(\mathrm{y})=0 \text { and } \mathrm{u}^{\prime \prime}(\mathrm{y})=0 \text { for } \mathrm{y} \geq T
$$

For the rich household, utility is always an increasing function of income. So

$$
\mathrm{U}_{\mathrm{R}}=\mathrm{u}(\mathrm{y}) \text { where } \mathrm{u}^{\prime}(\mathrm{y})>0 \text { and } \mathrm{u}^{\prime \prime}(\mathrm{y})<0 \text { for all } \mathrm{y}
$$

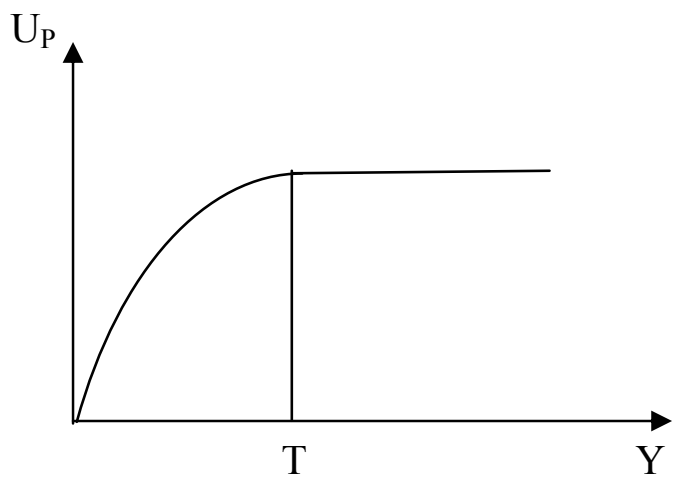

Figure 3: (a) Utility function of the poor household,

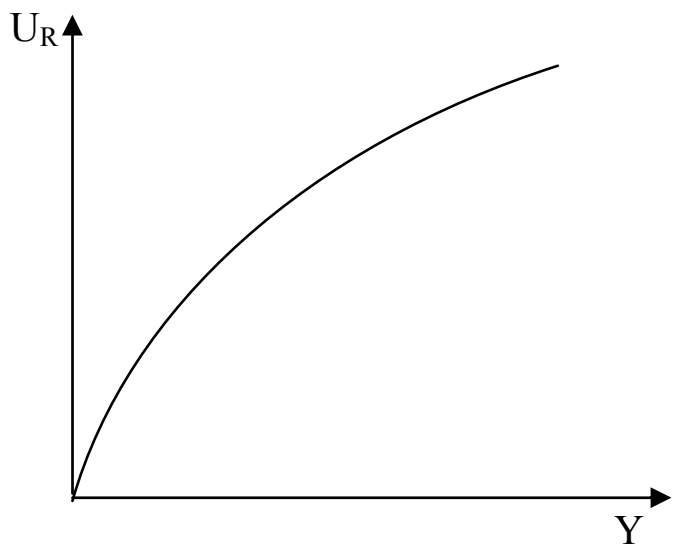

3: (b) Utility function of the rich household

The reason behind such a difference in the shape of the utility functions for the two types of household could be due to their relative access to certain goods and services. For rich the utility function is standard as more income makes them better off. This is due to the fact that rich household has access to banking sector both for credit and parking their savings. Their children would normally go to school creating opportunities for more income being productively spent. They will have better standard of living with other household accessories where additional income would create additional opportunities for deriving more utility. On the other hand, for the poor the above opportunities are very limited and additional income may not always involve productive spending leading to higher utility for them. In most cases, their children either do not go to school or go to free government schools. The poor typically also do not save in the Bank. Data on household expenditure from the National Sample Survey (NSS) also reveals that the scope for spending on goods and services other than the basic ones is very limited for the rural poor and hence the marginal utility of income after a level will be negligible in the short run. NSS data from 2007-08 reveals that the household expenditure on elastic items (medical, educational, entertainment, toiletries, footwear, consumer services etc.) is about Rs. 60 per month (15\% of total monthly per capita expenditure.

\subsection{Absence of NREGA}

Now consider the decision problem of the poor household in the above setup without the presence of NREGA programme. Given the labour days available with the family, they would have two options to allocate their total labour. Suppose the prevailing wage rate is w. First, consider the possibility of w > $\mathrm{w}^{*}$ : the case of labour surplus economy. In the prevailing wage there would be excess supply of 
labour. Each rich household would employ $1_{s}$ such that $f^{\prime}\left(K, L+l_{s}\right)=w$. So the total amount of labour demand would be m.1. $\mathrm{s}_{\mathrm{s}}$. Assuming that the total demand for labour is shared equally by all the poor households, each poor household would supply $\frac{m_{g}}{n}$. In such an economy, the poor family would try to reach as close to the income target as possible. Therefore, out of the rest of the labour $\left(L-\frac{m l_{s}}{n}\right)$, the poor household would employ on their own field so far as the marginal productivity of labour is zero. The excess labour remains totally unemployed due to the lack of opportunities. ${ }^{10}$

Next we move on to the possibility where there is no excess supply of labour at the prevailing wage and the market equilibrium can be obtained such that at a reasonable wage the demand and supply equate. However, the imperfection in the labour market manifests in the form a of lower prevailing wage than the equilibrium wage that could be ensured by the free play of demand and supply forces. This is the case of wage suppression mentioned earlier. Thus, we assume that $0<\mathrm{w}<\mathrm{w}^{*}$. Given the prevailing wage the poor household would employ a part, say $1_{\mathrm{p}}$, in their own field such that $\mathrm{f}^{\prime}\left(\mathrm{k}, 1_{\mathrm{p}}\right)=$ w. The remaining labour supply is $\mathrm{L}-1_{\mathrm{p}}{ }^{11}$ So there are two possibilities: either they supply the entire surplus labour to rich household or they supply less than the available labour days with them.

Case 1: Income below the target for the Poor: the poor household supply the entire surplus labour and get $w\left(L-1_{p}\right)$. Their total income is $f\left(k, l_{p}\right)+w\left(L-l_{p}\right)$. They will supply the entire surplus labour to the rich household at the prevailing wage, provided that

$$
\mathrm{f}\left(\mathrm{k}, \mathrm{l}_{\mathrm{p}}\right)+\mathrm{w}\left(\mathrm{L}-\mathrm{l}_{\mathrm{p}}\right)<\mathrm{T}
$$

Case 2: Income at the target for the Poor: If the opposite happens i.e., $f\left(k, l_{p}\right)+w\left(L-l_{p}\right)>T$, the poor household would not supply the entire surplus labour to the rich household. They will work for say $1_{\mathrm{s}}$ labour days for the rich household such that $\mathrm{f}\left(\mathrm{k}, \mathrm{l}_{\mathrm{p}}\right)+\mathrm{w} \mathrm{l}_{\mathrm{s}}=\mathrm{T}$. And as a result $1_{\mathrm{P}}+1_{\mathrm{s}}<\mathrm{L}$ (the poor household's endowment of labour).

Note that in case 1, at the prevailing wage, the entire excess labour days from all poor households is absorbed in the production of rich households and given that the prevailing wage is below the equilibrium wage $\mathrm{w}^{*}$, there would be excess demand for labour. The wage does not adjust to equilibrium given the labour market imperfection and the related socioeconomic factors, which keeps the wage lower than the equilibrium wage though there exist an upward pressure on the wage.

\footnotetext{
${ }^{10}$ Here we have presumed that with excess supply of labour it is not possible to reach the target income with such a low wage for the poor households.

${ }^{11}$ Note that if the wage rate $\mathrm{w}>\mathrm{w}_{\mathrm{h}}$ then the poor would decide not to cultivate their land and only supply the labour to the rich household. In that case $l_{p}=0$. This is the case when the poor households become agricultural labourers and stop cultivating their own land.
} 
On the other hand, in case 2 the poor household reaches their target income by their own cultivation and selling a portion of their surplus labour in the market. And given that the household has reached the target income, any increase in wage would bring down the total employment of labour of the poor household $\left(l_{\mathrm{P}}+1_{\mathrm{S}}\right)$. Now the supply of labour in response to the increase in wage to the rich household would depend on the sensitivity of the MPL in the poor household's land. Thus there is a substitution between the employment in own cultivation and market supply to rich household. It is possible that the market supply may be backward bending given that the overall choice of labour supply to own cultivation and market supply is diminishing in response to wage increase. With such a backward bending supply of labour it is conceivable that an equilibrium may not exist for small increase in wage and we may have a situation of excess demand for a wide range of wages. This happens due to the scarcity of labour. Another possibility could be the existence of multiple equilibria in the labour market. How far the wage would adjust to bring about an equilibrium in the labour market depends on the degree of imperfection. If the rich household can perfectly collude and set the wage for the labour market then they would set the wage at a level which maximises the total supply of labour to the rich households, that is the wage which just allow the poor households to reach their target incomes. This wage may not equal the equilibrating value.

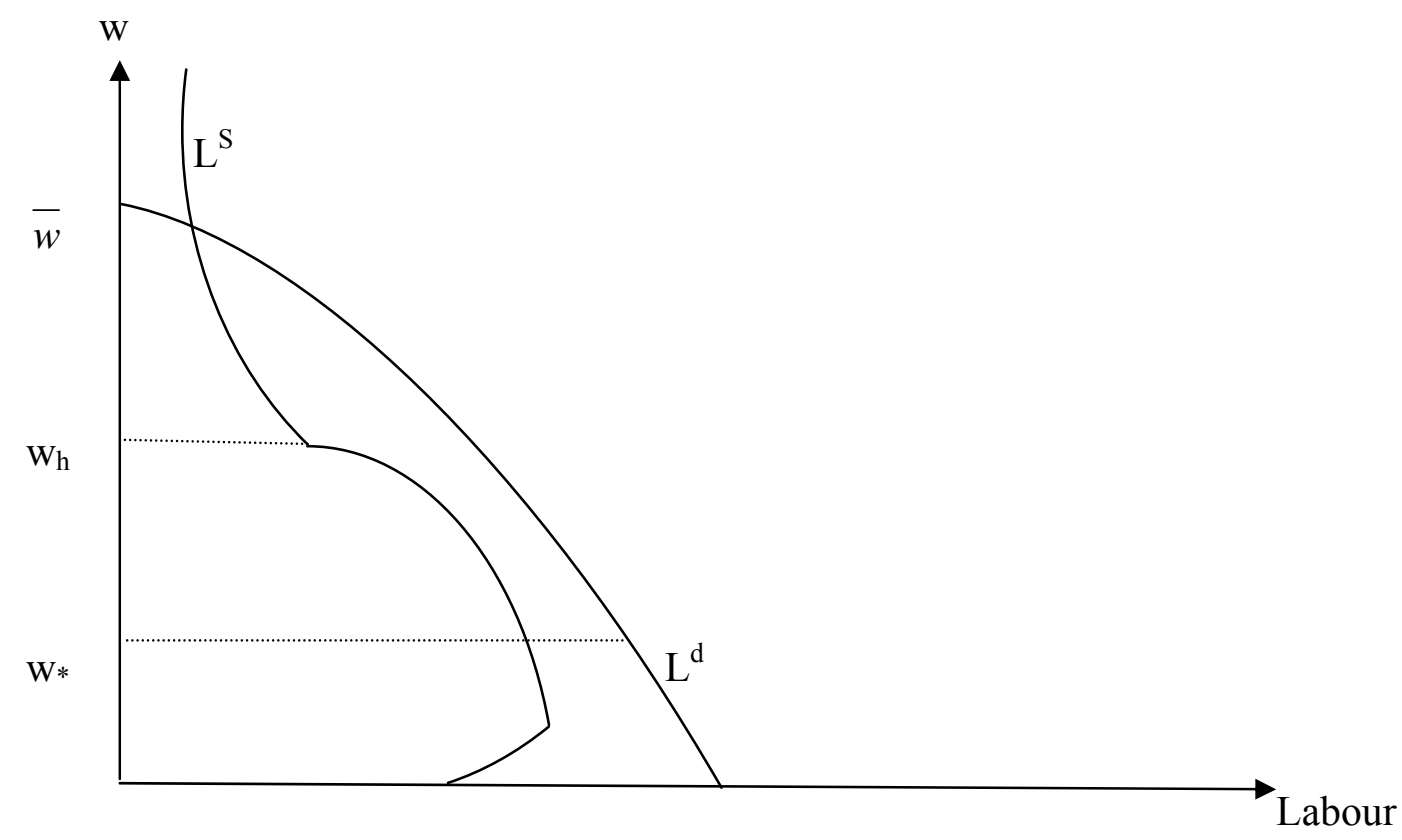

Figure 4: The labour supply from the poor households when their earnings are on target.

Case 1 is amply illustrated by the perfect labour market analysis in Figure 2. However, for Case 2, figure 4 would be useful to understand the outcome (Basu et al, 2010 consider a somewhat similar situation in terms of child labour supply). It is clear from the diagram that labour supply would be backward bending and there are possibilities of multiple equilibria in the labour market. It is also possible that even if the wages are allowed to adjust upward, the magnitude of adjustment has to be 
fairly large. It is also possible that after a large wage adjustment for an equilibrium, the poor household might stop cultivating their own land. ${ }^{12}$

The possible existence of inverse relationship between labour supply and wage for some categories of workers in developing countries was subject to scrutiny by various authors. Traditionally the study of backward-bending supply curve was based on the assumptions of "target income" (Berg, 1961), "'limited aspiration" (Mellor, 1963), and "subsistence mentality" (Lewis, 1954). An early study by Berg (1961) posed the problem in terms of 'target income' for the migrant labour in a dual economy structure and argued that "the aggregate labor supply function to any given country (say the Union of South Africa, or the Ivory Coast or Uganda) may have been backward-sloping in the early years of African development". Among some of the recent studies, the studies by Licona (2000) for Mexico, Dessing (2002) for Philippines, Bhalotra (2007) for child labour in Pakistan and El-Hamidi (2003) for female labour in Egypt and Sharif (1991) for Bangaldesh are noteworthy. In Indian context, Bardhan (1979) mentioned that "there seems to be some evidence for at least a locally back- ward-bending supply curve of labor for the set of all adult women (primarily house- wives) and of hired-out farm labor for the set of cultivators of all size groups taken together" in his sample of 8,500 rural workers from nearly 4,900 households drawn from about 500 sample villages belonging to the state of West Bengal. Lately, Goldar and Dasgupta (2005) investigated the issue for rural female labour supply using NSS data for 1999-2000 and they found that "supply of female labour from below poverty line households in rural areas is inversely related to wage rate and the number of earning members in the family" and thus, as early as 2005, they raised doubt about the efficacy of National Rural Employment Guarantee Scheme.

\subsection{Impact of NREGA}

Under NREGA a certain number of days of labour employment is provided by the government scheme. Assume that number to be $x$. In this section we consider the case where the NREGA work is just an employment scheme and no assets are created which influence the productivity of land. As a result the production functions for rich and poor households remain as they were before.

It is an empirical fact that the NREGA wage is higher than the prevailing wage rate in most areas (see Table 2, columns 5 and 6, a notable exception being the state of Gujarat). For a poor household there are three options to work and try to reach the target income. Assume the NREGA wage is $\mathrm{w}^{\mathrm{N}}>\mathrm{w}$, which is the prevailing wage.

\footnotetext{
${ }^{12}$ There is also the possibility that the poor households reach their target income only from cultivating their own land. In that case the labour market vanishes at the prevailing wage. We leave this uninteresting case out.
} 


\section{Case of labour surplus economy:}

In case of the labour surplus economy, the impact of NREGA depends on the relative magnitude of NREGA work and the amount of surplus labour in the economy. If the amount of NREGA work is below the surplus labour available in each poor household then there would be no impact of NREGA work on the employment decision for their own cultivation and the decision to supply labour for the rich households. As a result of NREGA work, the level of outputs in both rich and poor households remain the same but the NREGA work would increase the income of the poor households. This prediction is based on the presumption that that NREGA work of 100 labour days does not still allow the poor household to reach their target level of income (but it is still comparatively substantial as illustrated in Table 2, last 4 columns. Here it is seen that, assuming a household of size 5, the earnings from NREGA alone is sufficient to cover $30-50 \%$ of the income required to be above the poverty line. The percentage is closer to $60 \%$ assuming households with 4 members.). If the amount of NREGA works available is more than the surplus labour available in each poor household then there would be some change in the employment decision of the poor households and the analysis is similar to what is given below for any economy with or without surplus labour. This additional demand from NREGA work would reduce the supply of labour to the rich households.

The poor household try to maximise $y=f\left(k, l_{P}\right)+w^{N} \cdot x+w l_{s} \leq T$ subject to $1_{P}+x+1_{s} \leq L$.

Posssibility 1: if $y=f\left(k, l_{P}\left(w^{N}\right)\right)+w^{N} \cdot x \geq T$, then the poor household would not even undertake the full amount of NREGA work allotted to them. So they may not even work for $x$ labour days and would choose the amount of work $\mathrm{z} \leq \mathrm{x}$ such that $\mathrm{y}=\mathrm{f}\left(\mathrm{k}, \mathrm{l}_{\mathrm{P}}\left(\mathrm{w}^{\mathrm{N}}\right)\right)+\mathrm{w}^{\mathrm{N}} \cdot \mathrm{z}=T$. In this scenario the labour market would vanish. As compared to the regime without NREGA, it is clear that the agricultural production in poor households would be less, and also the production in the rich household would be less, leading to an overall adverse production effect. Though the presence of NREGA improves the lot of the poor but due to the labour shortage (in this case the labour supply for the rich household vanishes completely), the rich households would be worse off.

Possibility 2: if $\mathrm{y}=\mathrm{f}\left(\mathrm{k}, \mathrm{l}_{\mathrm{P}}(\mathrm{w})\right)+\mathrm{w}^{\mathrm{N}} \cdot \mathrm{x} \geq T>\mathrm{f}\left(\mathrm{k}, \mathrm{l}_{\mathrm{P}}\left(\mathrm{w}^{\mathrm{N}}\right)\right)+\mathrm{w}^{\mathrm{N}} \cdot \mathrm{x}$. The poor household would choose 1 for its own cultivation such that $1<1_{\mathrm{P}}(\mathrm{w})$ and $\mathrm{y}=\mathrm{f}\left(\mathrm{k}, \mathrm{l}_{\mathrm{P}}(\mathrm{w})\right)+\mathrm{w}^{\mathrm{N}} \cdot \mathrm{x}=T$. So they would not supply any labour to the rich household but only employ the labour for self cultivation and do the full amount of NREGA work and hence reach their target income. Here also the labour market vanishes altogether.

Possibility 3: when $\mathrm{y}=\mathrm{f}\left(\mathrm{k}, \mathrm{l}_{\mathrm{P}}(\mathrm{w})\right)+\mathrm{w}^{\mathrm{N}} \cdot \mathrm{x}<T$, the poor would still like to supply some labour to the rich households at the prevailing wage w. Now the poor household would supply (i) the entire surplus 
labour $\left.\mathrm{L}-\mathrm{l}_{\mathrm{P}}(\mathrm{w})\right)-\mathrm{x}$ if $\left.\mathrm{y}=\mathrm{f}\left(\mathrm{k}, \mathrm{l}_{\mathrm{P}}\left(\mathrm{w}^{\mathrm{N}}\right)\right)+\mathrm{w}^{\mathrm{N}} \cdot \mathrm{x}+\mathrm{w}\left(\mathrm{L}-\mathrm{l}_{\mathrm{P}}\left(\mathrm{w}^{\mathrm{N}}\right)\right)-\mathrm{x}\right)<T$. Or (ii) supply $\left.\mathrm{l}_{\mathrm{N}}<\mathrm{L}-\mathrm{l}_{\mathrm{P}}\left(\mathrm{w}^{\mathrm{N}}\right)\right)$ $-\mathrm{x}$ such that $\mathrm{y}=\mathrm{f}\left(\mathrm{k}, \mathrm{l}_{\mathrm{P}}\left(\mathrm{w}^{\mathrm{N}}\right)\right)+\mathrm{w}^{\mathrm{N}} \cdot \mathrm{x}+\mathrm{wl}_{\mathrm{N}}=T$.

Thus, we have three possible outcomes of the economy with the introduction of the NREGA scheme. There is no supply to the labour market and the target income of the poor is reached by their own cultivation and NREGA work (possibility 1 and 2). In possibility 3 the labour market exists and the target of the poor may or may not be reached.

It is obvious that, in the presence of NREGA, starting from the same situation, a poor household would supply less labour to the market than could be hired by the rich household. As a result there will be adverse production effect, and the poor household would be better off but the rich households would be worse off. Note that with the introduction of NREGA, given that the NREGA wage is higher than the prevailing market wage, the poor household would always prefer to work for the NREGA scheme. The market supply is only related to how the remaining labour days are being allocated between own cultivation and the market supply.

Remark: When the target of the poor households are fulfilled with only partial supply of their labour to the market then any attempt to increase the wage in the market for bringing more labour supply to the market may be counterproductive as the labour supply to the market would eventually be backward bending with large increase in the market wage w (possibility 3 above). On the other hand, when the target of the poor household is not reached even with supply of labour to the market, then with the increase in wage it is possible to bring forth more labour to the market.

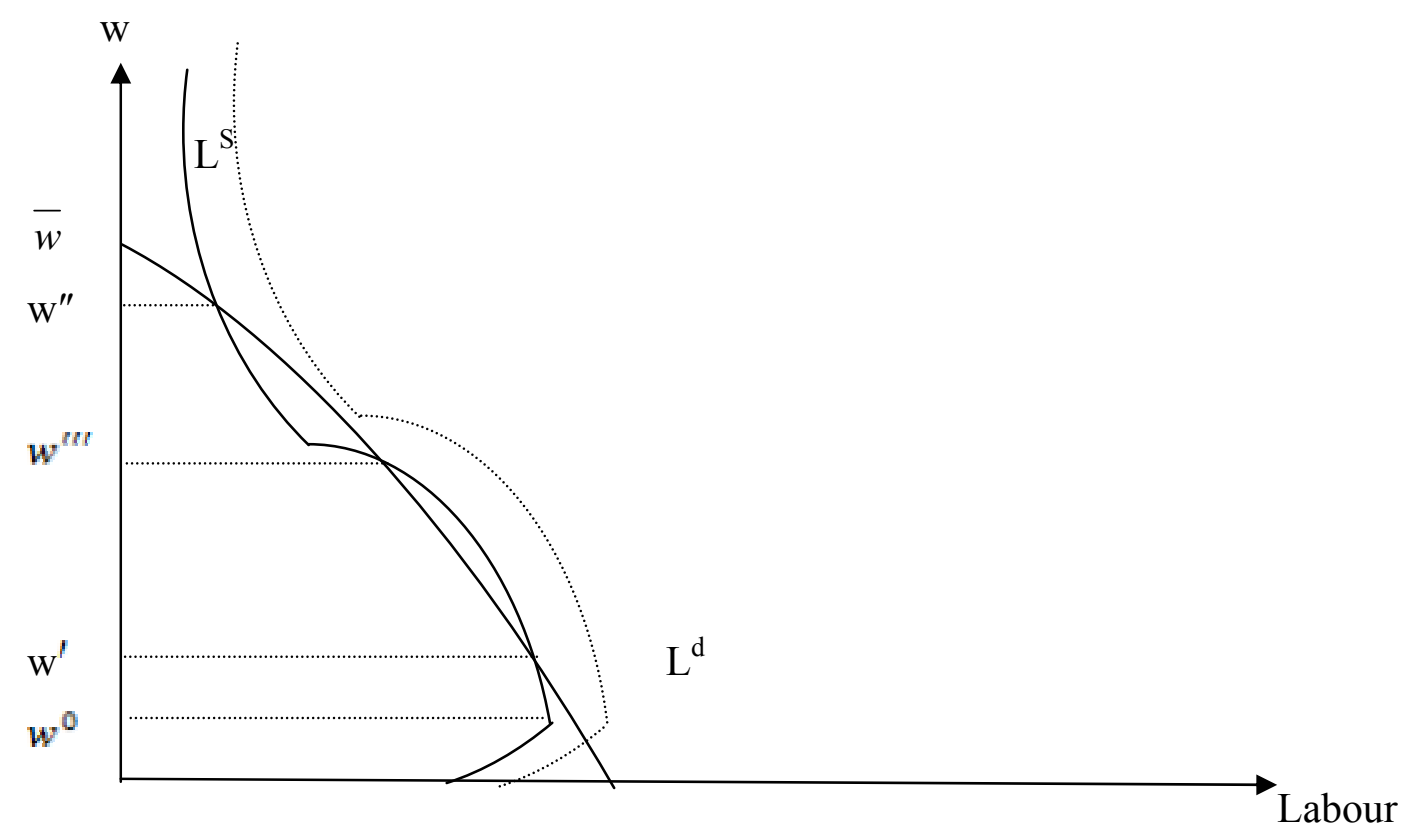

Figure 5. Possibility of multiple equilibria post NREGA 
The above figure shows the possibility of multiple equilibria after the NREGA scheme is implemented starting from an initial situation where there was only one equilibrium. There are three equilibria: two of them are stable and the middle one is unstable. If the market plays itself out perfectly then the equilibrium wages are all above the initial one. However, given the labour supply curve if the rich households can organise themselves and cooperate they would fix the wage at $w^{0}$, which would maximise the total labour supply to the rich households.

\section{NREGA - Productivity Link:}

The above observations are made with the assumption that NREGA work does not affect the production function of the agricultural sector at all. Since NREGA works are to create some social assets which would have impact on the productivity of the agriculture by facilitating irrigation and water conservation; roads and rural marketing etc,. we now introduce that NREGA work improves the productivity in agriculture by a factor $\varepsilon$. Thus the production function becomes $Q=(1+\varepsilon) f($.$) for both$ type of households. Given the public good nature of the asset creation to enhance productivity in agriculture we assume that the productivity increases symmetrically for both rich and poor households.

Now due to this productivity increase in the land the marginal productivity of labour shifts outwards for both households with fixed amount of land. Thus, for any prevailing wage the poor would like to employ more labour in their own land leaving less available for NREGA work or for the labour market. This rise in productivity increases the likelihood that the poor reaches their target income easily. Thus, the rise in productivity increases the chance either that the labour market vanishes or the poor household reaches their target income without supplying the whole surplus labour to the labour market.

First we consider the case of labour surplus economy. Suppose, the NREGA work is just sufficient to absorb the surplus labour from the economy. Given that labourers are fully employed there would be upward pressure on the wage to bring about more labour for the cultivation of rich household. Even if the wage increases in response to NREGA work or even if the level of employment in both rich and poor household remains the same absent NREGA work, production in both households increases and both the rich and poor households are better off. This situation can only arise if the poor households do not reach their target income even after the NREGA works provided to them. In case the poor reaches the target income and there is less or no supply of labour to the rich household, this would be a negative factor despite the increase in productivity. The overall effect on the level of production can go in either direction. 
Now we consider the situation where there exists a labour market in the absence of NREGA and the poor household does not reach their target income due to the low wage in the economy.

Consider the worst possible scenario in the absence of NREGA the poor households could not reach their target income even though they supply the surplus labour entirely to the market. Now with the introduction of NREGA the productivity of the land increases. This results into more labour to be employed in the land of poor household. Now even after undertaking the NREGA work there may or may not be surplus labour for the market. Consider the extreme form of productivity increase which is very high so that there is no surplus labour for the market and the poor households target incomes are reached. The labour market vanishes altogether. The poors are necessarily better off. The rich household would also be better off for very high productivity increase if the following condition is satisfied.

$(1+\varepsilon) \mathrm{f}(\mathrm{K}, \mathrm{L})>\mathrm{f}\left(\mathrm{K}, \mathrm{L}+\frac{m \cdot l_{s}}{n}\right)$

It is not so clear from the above expression what happens for a relatively small or moderate productivity increase. It would depend on the relative change in labour supply vis a vis the relative change in productivity and the effect can go either way. In general one can expect that if the NREGA leads to a relatively small productivity increase compared to a relatively large drop in the labour supply the overall production will go down, whereas if there is relatively large productivity increase and relatively little change in labour supply in response to NREGA there would be positive output effect.

\subsection{Numerical example:}

The following numerical example illustrates an interesting possibility where the output effect would be non-monotonic in relation to increase in productivity.

Consider a village with one rich household and three poor households. ${ }^{13}$ The rich household has a land holding of 625 units and each of the poor household has 4 units of land. The wage in the market is $\mathrm{w}=60$ and each household has the amount of labour available $\mathrm{L}=200$. The poor household has a target income $\mathrm{T}=12000$. The NREGA wage $\mathrm{w}^{\mathrm{N}}=100$ and the total amount of NREGA work available per household $\mathrm{x}=40$ labour days.

The agricultural production function: land $(k)$ and labour $(l)$

\footnotetext{
${ }^{13}$ One can increase the size of the village by replicating the number of households in the given proportion and all our results in this section would still hold true.
} 


$$
Q=(1+\varepsilon)\left\{100 \sqrt{k} l-2 l^{2}\right\}
$$

Given the production function the marginal productivity of labour is given by

$$
\frac{\partial Q}{\partial l}=(1+\varepsilon)\{100 \sqrt{k}-4 l\}
$$

Thus, the marginal productivity of labour is a linear function and attains zero at the level of employment $l=25 \sqrt{k}$. The marginal productivity of labour for rich household is :

$$
(1+\varepsilon)(2500-4 l) \text {. }
$$

Similarly, for the poor households: $\quad(1+\varepsilon)(200-4 l)$.

Note that this production function obeys the diminishing marginal productivity property for land as well. However, in case of land the marginal productivity curve is convex. Given the prevailing wage rate $\mathrm{w}=60$, the labour employment for each poor household in their own cultivation is given by $60=(1+\varepsilon)(200-4 l)$

So, $l=\frac{50 \varepsilon+35}{\varepsilon+1}$. Plugging this value of 1 in the production function gives us the output of the poor household $q=\frac{1}{\varepsilon+1}\left(5000 \varepsilon^{2}+10000 \varepsilon+4550\right)$

Labour supply of the poor household would be $l_{\xi}$, we must have own output +NREGA earning $(100 \mathrm{X} 40)+$ wage earning from rich household $=$ target income

$\frac{1}{\varepsilon+1}\left(5000 \varepsilon^{2}+10000 \varepsilon+4550\right)+4000+60 l_{s}=12000$

$l_{s}=\frac{1}{6 \varepsilon+6}\left(345-500 \varepsilon^{2}-200 \varepsilon\right)$

At $\varepsilon=0$ labour supply from a poor household is 57.5 .

On the other hand the labour supply to the market is zero when $\varepsilon=.6544$. So labour supply is positive for $0 \leq \varepsilon \leq .6544$ but it is decreasing as productivity parameter increases.

First, note that the rich household would be willing to employ at the prevailing wage $\mathrm{w}=60$ even when $\varepsilon=0$ is 610 units of labour days. They need to hire 410 whereas the supply from the three household is only 162.5 . Hence, there is a demand supply gap of labour even at $\varepsilon=0$.

Thus, by employing the available labour days from the market plus its own labour, the total output in the rich household is

$Q=\frac{1}{2 \varepsilon+2}\left(1307475+2064500 \varepsilon-45000 \varepsilon^{2}-1050000 \varepsilon^{3}-250000 \varepsilon^{4}\right)$

Thus total output in the economy (output of the rich household plus the outputs in three poor households) when there is positive supply of labour from the poor households to rich households is (after simplification) (for $0 \leq s \leq .6544$ ).

$\frac{25}{2 \varepsilon+2}\left(53391+84980 \varepsilon-600 \varepsilon^{2}-42000 \varepsilon^{3}-10000 \varepsilon^{4}\right)$ 
When the labour market vanishes that is for $\varepsilon>6544$, then the rich household employs its own labour and the poor households do their own farming and NREGA works such that the target income is reached. Three possible situations arise

(i) for $0.6544<\varepsilon<0.7434$ the poor supplies labour for full NREGA quota and employ labour to own cultivation to produce just 8000 .

(ii) for $0.7434<\varepsilon<1.5$, produce using the opportunity cost of labour as $\mathrm{w}^{\mathrm{N}}$ and earn the remaining income from NREGA but not supplying the whole quota such that the total earning is 12000. Thus, the production in the own cultivation is $\frac{1}{s+1}\left(5000 \varepsilon^{2}+10000 \varepsilon+3750\right)$

(iii) For $\varepsilon>1.5$, produce just 12000 don't supply labour to NREGA. This is a case of self sufficient family $^{14}$

As a result the total output in the economy would be for $0.6544<\varepsilon<0.7434$

$420000 \varepsilon+420000+24000=420000 \varepsilon+444000$

And for $.7434<\varepsilon<1.5$

$420000 \varepsilon+420000+\frac{3}{z+1}\left(5000 \varepsilon^{2}+10000 \varepsilon+3750\right)=\frac{1}{z+1}\left(435000 \varepsilon^{2}+8700000 \varepsilon+431250\right)$

$\frac{1}{\varepsilon+1}\left(435000 \varepsilon^{2}+870000 \varepsilon+433650\right)$

For different ranges of productivity parameter we can plot the behaviour of the total output of the economy as below (figure 5).

This shows that there exists a non-monotonic relationship between the increase in productivity and the total output produced in both poor and rich households together. For an initial range, the poor household still supplies labour to the rich household but this is decreasing. This two effects balances at a point $\varepsilon=.4124$ and then the output start falling up to $\varepsilon=.6544$. After that the labour market vanishes for the rich household and subsequent increase in productivity increases the total output in the economy. This is a very interesting result as the programme like NREGA despite having the strong productivity enhancement effect (up to 65\%) can still lead to decrease in total output in the economy.

\footnotetext{
${ }^{14}$ Note that if the poor household stops supplying labour then there would not be any NREGA and as a result no productivity gain. This process of productivity gain may require certain critical amount of labour supply for the NREGA scheme to create any productive asset. Thus, $\varepsilon$ would have an upper limit below 1.5 and above .7434 .
} 


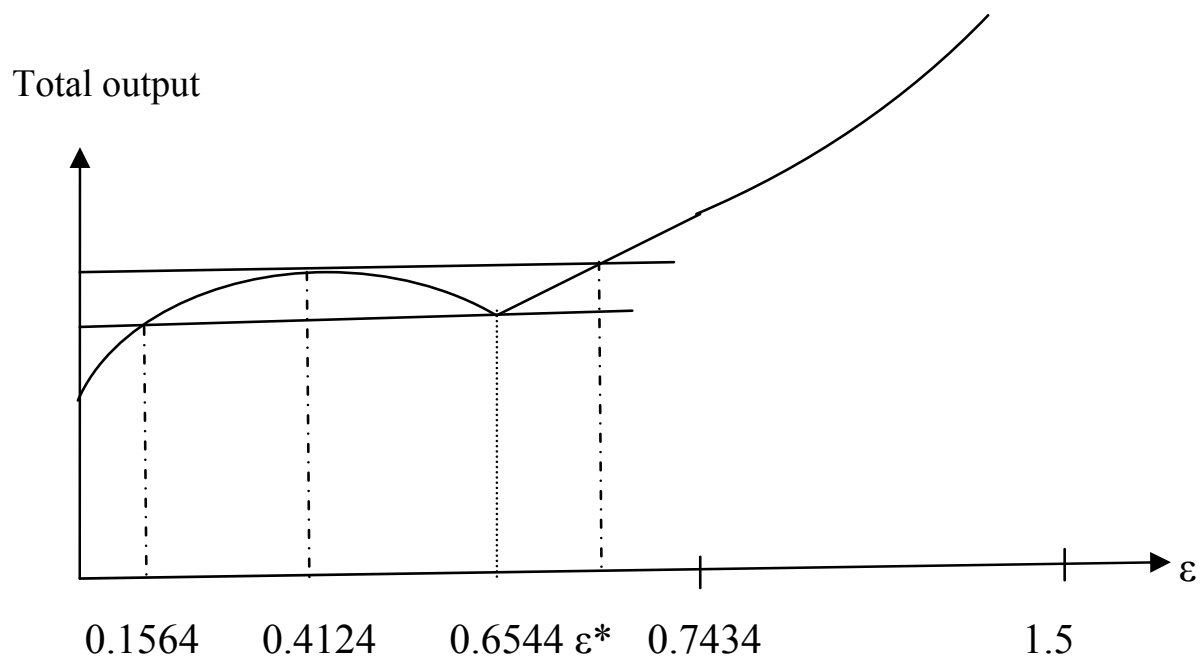

Figure 5: Total production for the example where $\varepsilon^{*}=.736$ (approximately).

Thus the output decreases when the increase in productivity is between .4124 and .6544 , beyond that the labour market vanishes and the output increases as productivity increases up to 1.5 at which the labour supply even for the NREGA work goes to zero. Thus, it is better for the society to have the productivity factor to take value 0.4124 than any value between 0.4124 and $\varepsilon^{*}$. The labour supply to NREGA work comes to a halt at $\varepsilon=1.5$ and so without the labour supply for NREGA the productivity increase cannot take place. The purpose of this example is illustrative and it is not conceivable that the productivity increase would at all take place so drastically from the NREGA scheme itself.

We have checked in the above example the behaviour of total output when there are one rich and only one poor households in the economy. Then the increase in productivity always leads to an increase in the total output in the economy. Thus we also demonstrate that the relative distribution of the rich and poor households in the economy is extremely important for understanding the effect of productivity increase on the overall output in agriculture as a result of NREGA scheme.

\subsection{Empirical Support}

\subsubsection{NREGA - Demand for Employment}

Nair et al (2009) studied the impact of the National Rural Employment Guarantee Programme in three Grama Panchayats of Kasaragod District of Kerala, namely Madikai, Ajanoor and Trikarpur. While the worker registration is appreciably good in all the three Grama Panchayats including registration of SC and ST categories, however, there is a sharp drop in the number of people who demanded jobs in 
2007-08 which was below one fourth in two Panchayats and just above one third in the third Panchayat. There was further drop in the number in the following year.

\subsubsection{NREGA - Productivity}

With the adverse production effect and increase in the income of the poor households who spend most part of their income on food and other essential items, the introduction of NREGA would necessarily lead to rise in food prices unless the food prices are stabilised with imports. Whether imports are a viable option for long term from the world market is another debate which we do not want to go into in this paper. To verify the price rise possibility, we look at the relative price of food items with respect to the CPI (consumer price index), particularly for the agricultural labourers (see figure 6(a)). It is apparent that there has been a sharp rise in the relative price of food items since the inception of NREGA in 2005. To check whether this has been due to a poor rainfall and hence overall decrease in agricultural production, in figure 6(b) we have also presented the rainfall deficit which does not show any clear linkage with the above cited price rise.

\section{Concluding Remarks}

A crucial dimension of the rural labour market is the target income of the poor. This target income is the root cause of the backward bending supply curve of labour in our analysis. So the policy focus should be to increase this target income by creating more market access and opportunities for the poor households and improving their standard of living. In other words, in the current scenario with limited opportunities for productive spending and market access, it is unlikely that just generating extra income would alone solve the problem. Consider a poor household who wants to buy a TV set or other electronic equipments which would improve their quality of living. But without electricity connection or with extremely irregular supply of electricity to rural areas it is impossible for a poor household to enjoy the benefit properly. As a result the household may prefer to live without such household accessories which otherwise would have improved the quality of their living. The similar problem of market access arises when it comes to educating their children. Even though the poor household is interested in good education of their children there may not be any good school in the neighbourhood. The poor households in most cases avoid banking sector for parking their savings as the process of dealing with a bank requires some level of education which most poor households do not have. Thus, to enhance the opportunities for the poor the policy should be inclusive and multipronged. Thus, the target income may be enhanced by creating opportunities and market access from multiple dimensions and not just an income generating scheme like NREGA can help to improve the situation of the poor households. 
In order to avoid the adverse production effect arising out of reduction of labour supply from the poor households, we need a direct policy of agricultural productivity increase such as another green revolution along with mechanisation so that a large part of agricultural activity can be done by machine which will replace the labour in agriculture. It is also important to revisit patterns of land holdings in states like West Bengal where the successful land reform has created too much fragmentation and such tiny plots of land are a deterrent for large scale mechanisation of agriculture. So we also suggest a consolidation of land holdings wherever necessary.

Most of our results are tentative predictions from a simple conceptual framework involving the NREGA scheme. Future researchers must investigate the truth of some of the predictions empirically. Our testable hypotheses are:

1. Wages have gone up in response to NREGA scheme.

2. Do people refuse to work even at higher wage in peak agricultural seasons (during sowing or harvesting seasons) while they have worked for NREGA in lean seasons?

3. There has been improvement in agricultural productivity due to NREGA.

4. There has been a net loss in agricultural production in sync with the implementation of NREGA.

Given the significant impact of NREGA scheme in the rural labour market as we have depicted in this paper it is possible to have a reverse migration from urban to rural areas. That is, we may observe a Lewis model in reverse, urban industrial workers coming back to agricultural area in search of easy NREGA wage. Though there is casual empirical evidence on this, however, no proper empirical study is available on this aspect of NREGA. 


\section{References}

Bardhan, Pranab, 1979. Labor supply functions in a poor agrarian economy. American Economic Review 69, 73-83.

Bardhan, Pranab, 1984. Land, Labor, and Rural Poverty: Essays in Development Economics. Oxford Univ. Press, Delhi.

Bardhan, Pranab K., Rudra, A., 1981. Terms and conditions of labour contracts in agriculture: results of a survey in West Bengal 1979. Oxford Bulletin of Economics and Statistics 43, 1 February.Bernstein, Irving, 1970. Turbulent Years: A History of the American Worker, 1933-1941. Houghton Mifflin, Boston.

Basu, Arnab K. 2007. "Impact of rural employment guarantee schemes on seasonal labor markets: optimum compensation and workers' welfare," College of William and Mary, mimeo.

Basu Arnab, Nancy Chau and Ravi Kanbur, 2005, The National Rural Employment Guarantee Act of India, Entry for the Oxford Companion to Economics in India.

Basu, Kaushik. 1981. "Food for work programmes: beyond roads that get washed away." Economic and Political Weekly, January 3-10

Basu, Kaushik. 1997. Analystical Development Economics: The Less Developed Economy Revisited, MIT Press, 1997.

Basu, Kaushik. Sanghamitra Das, Bhaskar Dutta, 2010, Child labor and household wealth: Theory and empirical evidence of an inverted-U, Journal of Development Economics 91, 8-14.

Berg, Elliot, 1961, "Backward-sloping labor supply function in dual economies -- African ease," Quarterly Journal of Economics, Vol. 75, No. 3, 468-492.

Besley, Timothy, Coate, Stephen, 1992. Workfare vs. welfare: incentive arguments for work requirements in poverty alleviation programs. American Economic Review 82 (2), 249-261.

Besley, Timothy, Kanbur, Ravi, 1993. Principles of targeting. In: Lipton, Michael, van de Gaag, Jacques (Eds.), Including the Poor: Proceedings of a Symposium Organized by the World Bank and the International Food Policy Research Institute. The World Bank, Washington D.C., pp. 67-90.

Bhalla, Surjit S, 2004, Ten Lies and an Act: I, Business Standard, December 25, 2004.

Bhalotra, Sonia . 2007, Is Child Work Necessary?. Oxford Bulletin of Economics and Statistics, Vol. 69 , No. 1, 29-55.

Binswanger, Hans P., Doherty, V.S., Balaramaiah, T., Bhende, M.J., Kshirsagar, K.G., Rao, V.B., Raju, P.S.S.,1984. Common features and contrasts in labor relations in the semiarid tropics of India. In: Binswanger, Hans, Rosenzweig, Mark (Eds.), Contractual Arrangements, Employments, and Wages in Rural Labor Markets in Asia. Yale University Press, New Haven, pp. 143-168. 
Blaug, Mark., 1963. The myth of the old poor law and the making of the new. Journal of Economic History $23,151-184$.

Blaug, Mark, 1964. The poor law report re-examined. Journal of Economic History 24, 229-245.

von Braun, Joachim, 1995. Employment for Poverty Reduction and Food Security. International Food Policy Research Institute, Washington DC.

Card, David, Krueger, Alan B., 1995. Myth and Measurement: The New Economics of the Minimum Wage. Princeton University Press, Princeton.

Dasgupta, Purnamita and Bishwanath Goldar, 2005, Female Labour Supply in Rural India: An Econometric Analysis, Discussion Paper, E/265/2005, Institute of Economic Growth, Delhi, India.

Datt, Gaurav, 1997. Bargaining Power, Wages and Employment: An Analysis of Agricultural Labor Markets in India. Sage Publications, London.

Dessing, Maryke, 2002, "Labour supply, the family and poverty: the S-shaped labour supply curve", Journal of Economic Behavior \& Organization, Vol. 49, 433-458

Dreze Jean and Khera, Reetika, 2009, The battle for employment guarantee, Frontline, 26 (01), Jan. 03-16.

Drèze, Jean, Sen, Amartya, 1991. Strategies of entitlement protection. Hunger and Public Action, pp. 104-121.

El-Hamidi, Fatima, 2003, "Poverty and Labour Supply of Women: Evidence from Egypt" Paper presented at Tenth Annual Conference of the Economic Research Forum, 16-18 December.

Hindustan Times, February 14, 2008

Kesselman, Jonathan R., 1978.Work relief programs in the Great Depression. In: Palmer, J.L. (Ed.), Creating Jobs: Public Employment Programs andWage Subsidies. Brookings Institution, Washington, D.C.

Lewis, W. A., 1954, "'Economic development with unlimited supplies of labor," Manchester School of Economics and Social Studies, Vol. 22, 139-91.

Licona, Gonzalo Henández, 2000, "Reshaping the Labour Supply Curve for the Poor", paper presented at the Annual Meeting of the Latin American and Caribbean Economic Association, Rio, 2000.

Lipton, Michael, 1996. Success in anti-poverty. Issues in Development Discussion Paper, vol. 8. International Labour Office, Geneva.

Manning, Alan, 2005. Monopsony in Motion: Imperfect Competition in Labor Markets. Princeton University Press, Princeton. 
Mathur, Lalit, 2007, Employment Guarantee: Progress So Far, Economic \& Political Weekly December 29, 2007

Mehrotra, Santosh, 2008, NREG Two Years On: Where Do We Go from Here?, Economic \& Political Weekly, August 2.

Nair, K. N., T.P. Sreedharan and M. Anoopkumar, 2009, A Study of National Rural Employment Guarantee Programme in Three Grama Panchayats of Kasaragod District, Working Paper 413, Centre for Development Studies, Trivandrum, India.

National Sample Survey: NSS Report no. 530, Household Consumer Expenditure in India, 2007-08, NSS 64th Round, July 2007 - June 2008.

National Sample Survey: NSS Report no. 509, Household Consumption of Various Goods and Services in India, 2004-05, NSS 61 st Round, July 2004 - June 2005.

Ravallion, Martin, 1990. Market responses to anti-hunger policies: effects on wages prices and employment. In: Drèze, J., Sen, A. (Eds.), The Political Economy of Hunger. Clarendon Press, Oxford.

Ravallion, Martin, 1991. Reaching the rural poor through EGS employment: arguments, lessons, and evidence from South Asia.World Bank Research Observer 6 (1), 153-176.

Ravallion, Martin, Datt, Guarav, Chaudhuri, S.,1993. Does Maharashtra's employment guarantee scheme guarantee employment? Effects of the 1988wage increase. Economic Development and Cultural Change 41 (2), 251-275.

Ray, Debraj, 1998, Development Economics, Princeton University Press.

\section{Web references:}

\section{http://www.agricoop.nic.in/}

\section{http://nrega.nic.in/netnrega/home.aspx}


Table 1: Some Performance Parameters for States and Districts - 2006-07

\begin{tabular}{|c|c|c|c|c|c|c|c|c|}
\hline \multirow[t]{2}{*}{ State } & \multirow[t]{2}{*}{\begin{tabular}{l|} 
No of \\
NREGA \\
Districts \\
\end{tabular}} & \multirow[t]{2}{*}{\begin{tabular}{|l|} 
Funds \\
Available \\
(Rs in cr) \\
\end{tabular}} & \multirow[t]{2}{*}{$\begin{array}{l}\text { Expen } \\
\text {-diture }\end{array}$} & \multirow[t]{2}{*}{$\begin{array}{l}\text { Percentage } \\
\text { Utilised }\end{array}$} & \multirow[t]{2}{*}{$\begin{array}{l}\text { Average Person } \\
\text { Days (in lakh) } \\
\text { per district }\end{array}$} & \multirow[t]{2}{*}{$\begin{array}{l}\text { Daily Unskilled } \\
\text { Wage Paid (Rs) } \\
\end{array}$} & \multicolumn{2}{|c|}{$\begin{array}{l}\% \text { of Households } \\
\text { Completed } 100 \text { Days of } \\
\text { Employment }\end{array}$} \\
\hline & & & & & & & 2006-07 & $2007-08$ \\
\hline Andhra Pradesh & 13 & 1142 & 680 & 59.6 & 52 & 86 & 2.7 & 9 \\
\hline Assam & 7 & 707 & & 83.7 & 82 & 67 & 23.4 & 17.1 \\
\hline Bihar & 23 & 1197 & 713 & 59.8 & 26 & 70 & 3.6 & 0.7 \\
\hline Chhattisgarh & 11 & 841 & 669 & 79.5 & 64 & 63 & 10.4 & 11.2 \\
\hline Gujarat & 6 & 124 & 85 & 69.4 & 17 & 56 & 5.4 & 3.9 \\
\hline Haryana & 2 & 47 & 36 & 77.3 & 12 & 97 & 11.1 & 10.4 \\
\hline Himachal Pradesh & 2 & 57 & 39 & 68.9 & 15 & 69 & 26.5 & 5.1 \\
\hline Jammu and Kashmir & 3 & 50 & 35 & 68.9 & 11 & 69 & 9.7 & 1.4 \\
\hline Jharkhand & 20 & 982 & 712 & 72.4 & 26 & 80 & 3.7 & 3 \\
\hline Karnataka & 6 & 341 & 248 & 72.8 & 37 & 67 & 12.8 & 4.2 \\
\hline Kerala & 2 & 48 & 28 & 57.7 & 10 & 121 & 0.5 & 32.1 \\
\hline Madhya Pradesh & 18 & 2134 & 1862 & 87.3 & 110 & 59 & 18.5 & 21 \\
\hline Maharashtra & 10 & 630 & 395 & 62.6 & 44 & 70 & 1.5 & 1.8 \\
\hline Meghalaya & 2 & 26 & & 81.7 & 12.1 & 73 & 0.6 & 6.4 \\
\hline Mizoram & 2 & 26 & & 63.2 & 3.9 & 175 & 11.7 & 0 \\
\hline Orissa & 19 & 890 & 733 & 82.4 & 42 & 53 & 11.1 & 3.4 \\
\hline Punjab & 1 & 38 & 25 & 65.1 & 11 & 96 & 16.8 & 5.3 \\
\hline Rajasthan & 6 & 856 & 693 & 81 & 167 & 51 & 54.4 & 42 \\
\hline Sikkim & 1 & 5 & & 57.4 & 2.4 & 87 & 5.4 & 10.2 \\
\hline Tamil Nadu & 6 & 252 & 151 & 60.2 & 31 & 80 & 0.3 & 6.2 \\
\hline Tripura & 1 & 50 & & 90.6 & 50 & 60 & 26.3 & 0.4 \\
\hline Uttar Pradesh & 22 & 1029 & 780 & 75.8 & 37 & 56 & 6 & 10.9 \\
\hline Uttarakhand & 3 & 71 & 48 & 68.3 & 13 & 72 & 2.8 & 8.3 \\
\hline West Bengal & 12 & 486 & 174 & 35.9 & 13 & 104 & 0.6 & 0.8 \\
\hline All India & 200 & 12073 & 8823 & 73 & $90.51 \mathrm{cr}$ & 65 & 10.2 & 10.8 \\
\hline
\end{tabular}


Table 2: Importance of NREGA wage in pushing families above poverty line.

\begin{tabular}{|c|c|c|c|c|c|c|c|c|c|c|c|c|}
\hline \multirow[t]{2}{*}{ State } & \multirow[t]{2}{*}{$\begin{array}{l}\text { Rural } \\
\text { Poverty } \\
\text { Line }\end{array}$} & \multirow[t]{2}{*}{$\begin{array}{l}\text { Poor } \\
\% \text { age }\end{array}$} & \multirow[t]{2}{*}{$\begin{array}{l}\text { Poor } \\
\text { Persons } \\
\text { lakhs }\end{array}$} & \multirow[t]{2}{*}{$\begin{array}{l}\text { Avg. } \\
\text { Agri. } \\
\text { Wage, } \\
\text { Men }\end{array}$} & \multirow[t]{2}{*}{$\begin{array}{l}\text { NREGA } \\
\text { wage }\end{array}$} & \multicolumn{2}{|c|}{$\begin{array}{l}\text { Employment } \\
\text { Provided -Number } \\
\text { of Person-days Per } \\
\text { Household }\end{array}$} & \multirow[t]{2}{*}{$\begin{array}{l}\text { NREGA } \\
\text { income }\end{array}$} & \multirow[t]{2}{*}{$\begin{array}{l}\text { Pov annual } \\
\text { income, } \\
\text { family of } 4\end{array}$} & \multirow[t]{2}{*}{$\begin{array}{l}\text { NREGA } \\
\text { /Pov. } \\
\text { Ratio } \\
\end{array}$} & \multirow[t]{2}{*}{$\begin{array}{l}\text { Pov annual } \\
\text { income, } \\
\text { family of } 5\end{array}$} & \multirow[t]{2}{*}{$\begin{array}{l}\text { NREGA/P } \\
\text { ov. Ratio }\end{array}$} \\
\hline & & & & & & $2006-07$ & $2007-08$ & & & & & \\
\hline Andhra Pradesh & 292.95 & 11.2 & 64.7 & 36.61 & 80 & 31.4 & 39.6 & 8000 & 14061.60 & 56.89 & 17577.00 & 45.51 \\
\hline Assam & 387.64 & 22.3 & 54.5 & 30.23 & 66 & 72.5 & 34.7 & 6600 & 18606.72 & 35.47 & 23258.40 & 28.38 \\
\hline Bihar & 354.36 & 42.1 & 336.72 & 45.06 & 77 & 35.3 & 21.1 & 7700 & 17009.28 & 45.27 & 21261.60 & 36.22 \\
\hline Gujarat & 353.93 & 19.1 & 63.49 & 55.48 & 50 & 43.7 & 29.6 & 5000 & 16988.64 & 29.43 & 21235.80 & 23.55 \\
\hline Haryana & 414.76 & 13.6 & 21.49 & 57.83 & 99.21 & 48.2 & 50 & 9921 & 19908.48 & 49.83 & 24885.60 & 39.87 \\
\hline Himachal Pradesh & 394.28 & 10.7 & 6.14 & 12.95 & 75 & 49.8 & 35.9 & 7500 & 18925.44 & 39.63 & 23656.80 & 31.70 \\
\hline Jammu \& Kashmir & 391.26 & 4.6 & 3.66 & 31.82 & 70 & 26.9 & 31.7 & 7000 & 18780.48 & 37.27 & 23475.60 & 29.82 \\
\hline Karnataka & 324.17 & 20.8 & 75.05 & 49 & 74 & 41.1 & 44.4 & 7400 & 15560.16 & 47.56 & 19450.20 & 38.05 \\
\hline Kerala & 430.12 & 13.2 & 32.43 & 55.89 & 125 & 22.8 & 28.6 & 12500 & 20645.76 & 60.55 & 25807.20 & 48.44 \\
\hline Madhya Pradesh & 327.78 & 36.9 & 175.65 & 40.61 & 67 & 68.9 & 63.3 & 6700 & 15733.44 & 42.58 & 19666.80 & 34.07 \\
\hline Maharashtra & 362.25 & 29.6 & 171.13 & 52.97 & 69 & 40.8 & 39 & 6900 & 17388.00 & 39.68 & 21735.00 & 31.75 \\
\hline Orissa & 325.79 & 46.8 & 151.75 & 44.86 & 70 & 57.5 & 37 & 7000 & 15637.92 & 44.76 & 19547.40 & 35.81 \\
\hline Punjab & 410.38 & 9.1 & 15.12 & 32.01 & 94.48 & 52 & 10.5 & 9448 & 19698.24 & 47.96 & 24622.80 & 38.37 \\
\hline Rajasthan & 374.57 & 18.7 & 87.38 & 44.16 & 73 & 85.4 & 75 & 7300 & 17979.36 & 40.60 & 22474.20 & 32.48 \\
\hline Tamil Nadu & 351.86 & 22.8 & 76.5 & 60.79 & 80 & 26.9 & 57.2 & 8000 & 16889.28 & 47.37 & 21111.60 & 37.89 \\
\hline Uttar Pradesh & 365.84 & 33.4 & 473 & 47.79 & 100 & 32 & 33.1 & 10000 & 17560.32 & 56.95 & 21950.40 & 45.56 \\
\hline West Bengal & 382.82 & 28.6 & 173.22 & 44.58 & 70 & 14.3 & 22.5 & 7000 & 18375.36 & 38.09 & 22969.20 & 30.48 \\
\hline All India & 356.30 & 28.3 & 2209.24 & & & 43.1 & 41.8 & & & & & \\
\hline
\end{tabular}



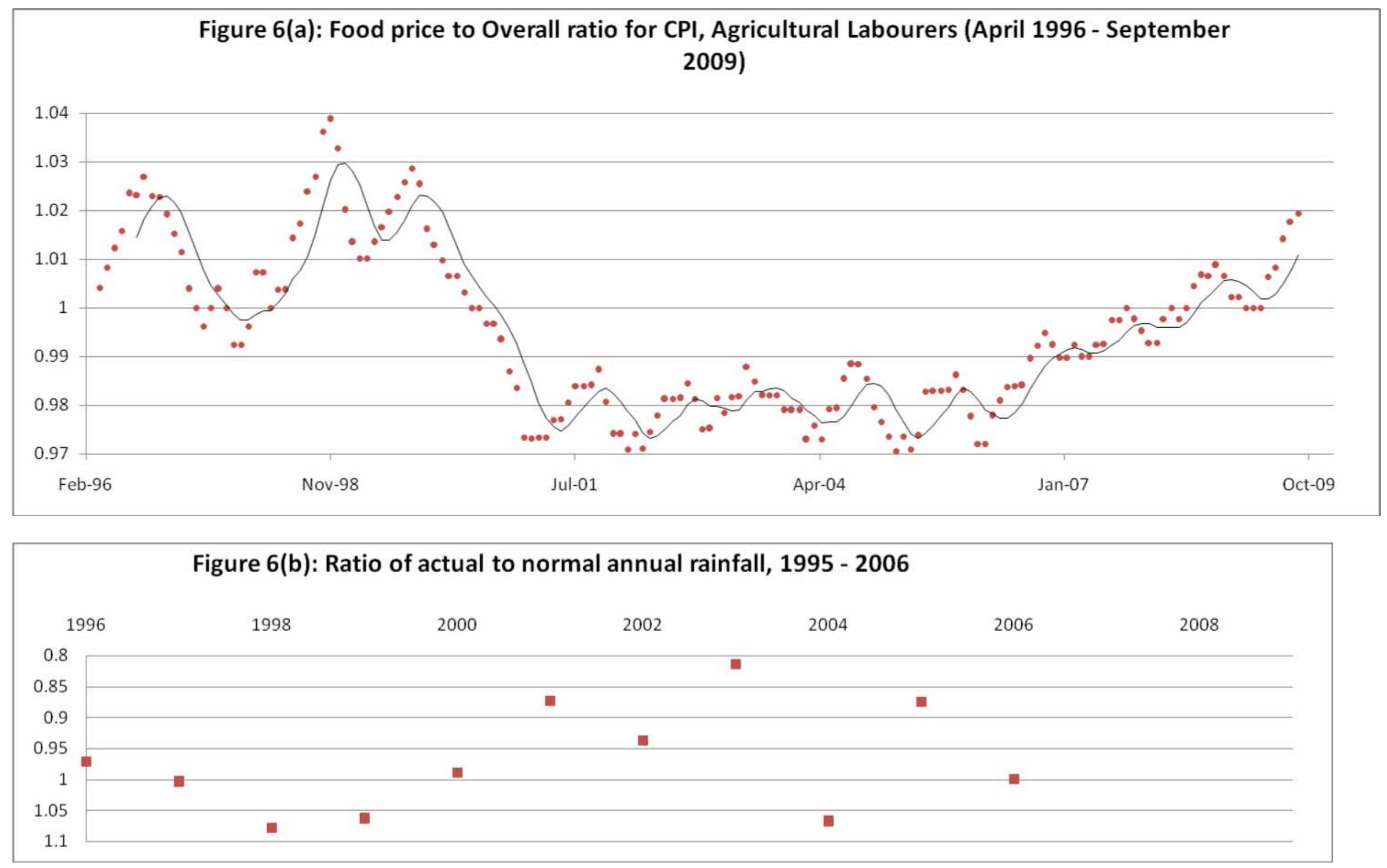